\title{
Cloning of Glucuronic Acid Transferases and HNK-1 Epitope
}

\author{
グルクロン酸転移酵素のクローニングとHNK-1エピトープ
}

Key Words : chondroitin sulfate, glucuronyltransferase, HNK-1 epitope

In 1975, Köler and Milstein reported a method for somatic cell hybridization, which would be applied for the production of monoclonal antibodies, and in 1977 detailed conditions were reported for the use of polyethylene glycol, which induces fusion between myeloma and activated lymphocytes and replaced the tedious procedure involving Sendai virus. HNK-1 is one of the monoclonal antibodies produced these days. The actual function of the molecules having the HNK-1 epitope, $\mathrm{SO}_{4}-3 \mathrm{GlcA} \beta 1-3 \mathrm{Gal} \beta 1-4 \mathrm{GlcNAc}$, on human NK cells still seems unclear, and neuroscientists will arrive at an answer for the function of HNK-1 epitope in neural tissues before immunologists can do so for the immunological functions. The HNK-1 glycochain was found in neural adhesion molecules like N-CAM, myelin-associated glycoprotein, L1, contactin, and P0. The expression of the HNK-1 epitope is spatially and developmentally regulated in the nervous system, and is found on migrating neural crest cells, cerebellum, and myelinating Schwann cells in motor neurons.

Kawasaki's group has succeeded in the purification of glucuronyltransferase responsible for the production of HNK-1 epitope and the cloning of its cDNA [Terayama, K., et al. (1998) J. Biol. Chem. 94, 6093-6098]. It provided an essential prerequisite for further molecular biological studies on the functions of HNK-1 glycochain. At first, they characterized UDPGlcA:Gal $\beta 1-4$ GlcNAc $\beta 1$ - $\beta$-1,3-glucuronyltransferases in rat brain and demonstrated that there are two types of transferases, one taking neolactotetraosylceramide as the substrate and the other asialoorosomucoid glycoprotein [Oka, S., et al. (1992) J. Biol. Chem. 267, 22711-22714]. Then, they purified the glucuronyltransferase taking glycoprotein as the substrate, which was separated from glycolipid-specific glucuronyltransferase by UDP-GlcA-conjugated Sepharose column. On the basis of partial amino acid sequence of the purified enzyme, a full-length GlcA transferase cDNA was isolated from rat embryonic brain cDNA library [Terayama, K., et al. (1998) Pro. Natl. Acad. Sci. USA, 94, 6093-6098]. The cloned cDNA encodes a protein with 347 amino acid residues, indicating a typical type II transmembrane protein. They found that four motifs in the catalytic domain are highly conserved in C. elgans and $S$. mansoni, and the presence of HNK-1 epitope in C. elegans supports the possibility of the presence of homologous glucuronyltransferase in lower animals. Northern blotting indicated the presence of mRNA only in the brain but not in the visceral organs including sciatic nerve fibers, lymph nodes, and spleen.
1975 年に Köler と Milstein は体細胞融合を報告し、この方 法がモノクローン抗体作製に応用できるであろうことが示され た。1977年にポリエチレングリコールの詳しい使用法が報告さ れて、ミエローマ細胞と活性化したリンパ球を融合するために それまで使われていた面倒なセンダイウイルスを使う方法に とって代わった。HNK-1はこの時代に免疫学者によって作られ たモノクローン抗体の一つであり、ヒトのNK細胞の HNK-1 エ ピトープ $\mathrm{SO}_{4}-3 \mathrm{GlcA} \beta 1-3 \mathrm{Gal} \beta 1-4 \mathrm{GlcNAc}$ を持つ分子の機能はま だ不明のままである。しかし、神経科学者は免疫学者よりも一 足先にHNK-1エピトープの機能を神経系で明らかにできるかも 知れない状況になってきている。HNK-1 糖鎖は N-CAM、ミエ リン結合性糖タンパク質、L1、P0等の神経接着分子構造に見い 出され、HNK-1の発現は神経系で空間的に、発生学的に制御さ れていて、移動する神経稜細胞、小脳、運動ニューロンのミエ リンを形成するシュワン細胞上に見い出されている。

川龒らはHNK-1 エピトープを作り出すグルクロン酸転移 酵素の精製、さらに、そのcDNAクローニングに成功した [Terayama, K., et al. (1998) J. Biol. Chem. 94, 6093-6098]。この ことは、HNK-1糖鎖機能に関する今後の分子生物学的な研究に 重要な糸口を提供するものである。最初に、彼等はラット脳の

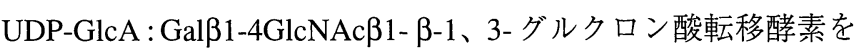
調べ、二つの酵素、neolactotetraosylceramide を基質とする酵素 とアシアロオロソムコイド糖タンパク質を基質とする酵素の存 在を明らかにした [Oka, S., et al. (1992) J. Biol. Chem. 267, 22711-22714]。その後、彼等はUDP-GlcA 結合セファロースカ ラムを使って糖タンパク質を基質とする酵素を糖脂質を基質と する酵素から分離し、精製することができた。精製酵素の部分 アミノ酸配列を基に、ラット胎児脳の cDNA ライブラリーから 全長のグルクロン酸転移酵素 cDNAを得た [Terayama, K., et al. (1998) Pro. Natl. Acad. Sci. USA, 94, 6093-6098]。cDNA は347ア ミノ酸から成るII型の膜タンパク質をコードしていた。酵素の 活性部位に相当する部分にC. エレガンス、マンソン住血吸虫で も保存されている4つのモチーフがあることを見い出した。C. エレガンスでHNK-1エピトープが検出されていることは下等動 物で類似のグルクロン酸転移酵素の存在することを支持してい る。ラット各種臓器のノーザン解析で脳にのみmRNAの存在が 
The authors indicated the possibility of low concentration of mRNA in a sciatic nerve, and they mentioned that RT-PCR can detect signals using sciatic nerve fiber mRNA as a template. The transfection experiment with Lec2 cells demonstrated that the cloned cDNA can produce GlcA $\beta 1-3 \mathrm{Gal} \beta 1-4 \mathrm{GlcNAc} \beta 1$ epitope on the cell surface of the cells. The transfection to COS- 1 cells produced the HNK-1 epitope on the cell surface because of the the presence of sulfotransferase acting on the product by the glucuronyltransferase, and the transfectant exhibited a drastic cell shape change, which is the formation of long and branched processes with irregular shapes. These changes suggest that the HNK-1 epitope may modulate the cellsubstratum interaction and rearrange cytoskeletal proteins in the cells.

Kitagawa et al. successfully applied the sequence of the above glucuronyltransferase to the cloning of another glucuronyltransferase responsible for the biosynthesis of the common carbohydrate-protein linkage structure of sulfated glycosaminoglycan (GAG), GlcAß1-3Galß1-3Galß1-4Xy1ß1-O-Ser [Kitagawa, H., et al. (1998) J. Biol. Chem. 273, 6615-6618]. They took advantage of the four highly conserved motifs in the catalytic region among rat glucuronyltransferase and putative proteins of $C$. elegans and $S$. mansoni, as mentioned above, to clone a new member of this gene family from human placenta. They designed degenerative primers for the conserved elements of the two motifs out of the four, and chose human placenta as a source of cDNA because of the abundant occurrence of sulfated GAG and absence of the glucuronyltransferase using glycoprotein as the substrate. A $210 \mathrm{bp}$ fragment was amplified by PCR, and a complete coding sequence was cloned by 3'/5' rapid amplification of cDNA ends. The cDNA sequence thus obtained indicated a single open reading frame of $1005 \mathrm{bp}$ encoding for a protein of 335 amino acids, which contains one potential membrane-spanning region. A recombinant soluble enzyme fused with the protein A binding IgG domain took Gal $\beta 1-3 \mathrm{Gal} \beta 1-4 \mathrm{Xyl} \beta 1-\mathrm{O}-\mathrm{Ser}$ as the substrate but not other oligosaccharides including Gal $\beta 1-3 \mathrm{GlcNAc}$. The product of the enzymatic reaction was confirmed to be Glc $A \beta 1-3 \mathrm{Gal} \beta 1$ $3 \mathrm{Gal} \beta 1-4 \mathrm{Xyl} \beta 1-\mathrm{O}-\mathrm{Ser}$ by reversed phase HPLC. These results confirm that this glucuronyltransferase is distinct from that responsible for the formation of the repeating disaccharide units of chondroitin sulfate, as already proposed.

Glucuronyltransferases involved in the synthesis of glycolipid HNK-1 epitope and the repeating disaccharide units of chondroitin sulfate are not cloned yet. However, these recent two papers will trigger functional studies of glucuronic acid containing glycochains in vivo and ex vivo.

\section{Reported by Suzuki, A.}

The Tokyo Metropolitan Institute of Medical Science Honkomagome, Bunkyo-ku, Tokyo, 113-0021

FAX: 81-3-5685-6607
確認されたが、座骨神経、リンパ節、脾臓を含む内蔵組織には 検出されなかった。著者らは、座骨神経の RT-PCR でシグナル が検出し、少量のメッセージの存在を確認している。Lec2 細胞 にcDNA を強制発現させると、細胞表面に GlcA $11-3 \mathrm{Gal} \beta 1$ 4GlcNAc $\beta 1$-エピトープがつくりだされた。COS-1細胞に強制発 現させるとHNK-1エピトープが作り出されたが、これはグルク ロン酸転移酵素によって作られた糖鎖に内在性の硫酸転移酵素 が働き、エピトープが形成されたと考えられる。強制発現され た細胞は形態が大きく恋化し、長い分岐する不規則な突起を形 成した。これらの変化はHNK-1エピトープが細胞と基質間の相 互作用を変化させ、細胞内で骨格タンパク質の再構築を促した ことを示唆している。

北川らは、上記のグルクロン酸転移酵素の配列を硫酸化グ リコスアミノグリカンに共通の糖鎖タンパク結合構造、GlcAB1-

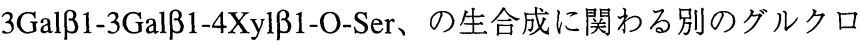
ン酸転移酵素のクローニングに応用し、成功した [Kitagawa, H. et al. (1998) J. Biol. Chem. 273, 6615-6618]。彼等はラットのグ ルクロン酸転移酵素と上記のC. エレガンス、マンソン住血吸虫 のタンパク質でも保存されていた 4 つのチーフを利用して、 ヒトの胎盤から同じ遺伝子ファミリーに属する新しいメンバー をクローニングした。彼等は保存されている4つのモチーフの

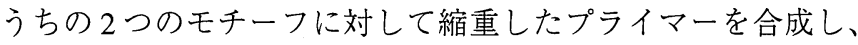
硫酸化GAGが豊富に存在し、しかも、糖タンパク質を基質とす るグルクロン酸転移酵素の存在しないヒトの胎盤をcDNA源と した。210 bpのDNA断片が増幅され、3’および5'RACE法で全 長のcDNAをクローニングした。得られたcDNAは $1005 \mathrm{bp} か ら$ なり、335アミノ酸をコードし、膜貫通部分を一籄所持ってい た。IgG 可溶性融合タンパク質として COS- 1 細胞に発現させた

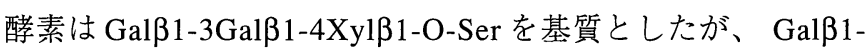
4GlcNAc を含むオリゴ糖は基質としなかった。酵素反応産物は

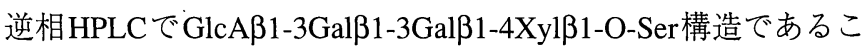
とを確認した。これらの結果からこのグルクロン酸転移酵素は、 既に示唆されていたように、コンドロイチン硫酸鎖の繰り返し 2 糖の形成に関与する酵素とは異なることが確認された。

糖脂質性の HNK-1 エピトープあるいはコンドロイチン硫 酸の繰り返し 2 糖合成に関与するグルクロン酸転移酵素はまだ

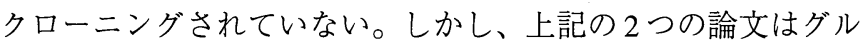
クロン酸糖鎖の生体内、生体外試験管内での機能研究への大き なきっかけを作った。

\section{東京都臨床医学総合研究所}

鈴木 明身 